\title{
The influence of change in mining and ground support practice on the frequency and severity of rockbursts
}

\author{
P Morissette University of Toronto, Canada \\ J Hadjigeorgiou University of Toronto, Canada \\ AR Punkkinen Vale Canada Ltd., Canada \\ DR Chinnasane Vale Canada Ltd., Canada
}

\begin{abstract}
The assessment of the performance of ground support systems under dynamic loading is typically subjected to qualitative and subjective interpretations. As a result, it is difficult to develop an explicit knowledge of the mechanisms of action and interaction of support elements subjected to rockbursts. This paper examines rockbursts that occurred at Creighton and Copper Cliff mines since 2000 and 2004, respectively. The majority of pertinent information was obtained through onsite field assessments, seismic system records, and numerical elastic stress modelling. Passive monitoring is used to link the evolution of the frequency and severity of rockbursts to the evolution of mining and support practice at the two mine sites. Based on the collected data, ground-support elements that enhanced the capacity of support systems to withstand dynamic loads are identified.
\end{abstract}

\section{Introduction}

The selection of appropriate mining methods, extraction sequences, rock mass preconditioning and destress techniques, and ground support systems is of great importance in mitigating the level of rockburst related risk. In burst-prone conditions, the selection of support systems should account for the anticipated dynamic load and the capacity of the available support options. Furthermore, an economical design should, implicitly or explicitly, take into consideration the consequences of a rockburst and its impact on the safety of mine personnel and mine productivity. Stacey (2012) has argued that designers suffer from limited understanding of the mechanisms of rock mass behaviour in seismic conditions. This is also compounded by a lack of understanding of the mechanisms of action and interaction of support elements under dynamic loads (Stacey 2012, p. 137). Consequently, the design of support systems required to manage dynamic loading is usually based on experience. The assessment of the dynamic performance of ground support systems is typically subjected to qualitative (and sometimes subjective) interpretations from mine operators. This can be referred to as perceived as opposed to demonstrated performance of support.

Passive monitoring is a useful tool in assessing the performance of ground support systems. Forensic analyses, in the context of rock support in burst-prone ground, is the assessment of the damage to an excavation or its support with the purpose of identifying the cause(s) of failure and/or validating design parameters (Kaiser \& Cai 2013). This information can be used to propose remediation strategies or the design of new reinforcement elements (Li 2010, 2012; Li \& Doucet 2012) or ground support systems. Passive monitoring based on reviews of historical rockburst data, on the other hand, can trace the evolution of mining and support practice at a mine site and its relation to the frequency and severity of rockbursts. This type of analysis, based on observed improvements in managing the consequences of rockburst, can justify changes in mining strategy and/or support practice. This paper illustrates lessons learned by monitoring changes in mine design and support with reference to rockburst case studies from two high stress underground mines. 
Unusual Occurrence Reports for Groundfalls/Rockbursts (Mines and Aggregates Safety and Health Association [MASHA] 2009) were collected at Vale's Creighton and Copper Cliff (formerly Copper Cliff North) mines. The two mines are located in the South Range of the Sudbury Basin, near Sudbury, Ontario. Each site employs dedicated ground control personnel. This has ensured continuity in the quality of the collected data. Information from onsite assessments was cross-validated with information obtained through seismic monitoring systems, geology mapping layouts, external reports, and site inspections. A retrievable database was constructed of 183 damage observations from Creighton and 35 from Copper Cliff. The evolution of rockbursts over time at these two sites is analysed in this paper. This is the continuation of previous work (Morissette et al. 2014).

\section{$2 \quad$ History of rockbursts at Creighton and Copper Cliff mines}

Creighton and Copper Cliff mines operate at different depths and are located within several lithological units. The majority of rockburst case studies in this analysis were associated with mining of the Deep 400 and 461 orebodies at Creighton and the 100 and 900 orebodies at Copper Cliff. These four orebodies are represented on the same scale in order to illustrate variations of depth and size between the two mines (Figure 1). Slot and slash, a variation of open stope mining, is the predominant mining method at both sites. The Deep 400 and 461 orebodies at Creighton are mined using a top-down, centre-out sequence in order to accommodate higher levels of mining-induced stresses and seismicity. At Copper Cliff, on the other hand, mining progresses using a bottom-up sequence. A comprehensive review of the geology and rock mass properties at Creighton and Copper Cliff mines has been presented by Morissette et al. (2014). Rock mass classification and stress conditions for the two mines are presented in Figure 2, after Martin et al. (1999). In this conceptual diagram the observed conditions suggest the potential for brittle rock mass failure and unravelling.

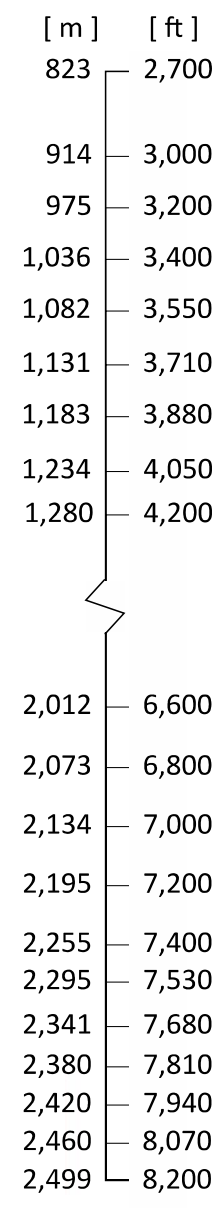

Figure 1 Relative depth and volume of orebodies associated with the majority of rockburst case studies at Creighton and Copper Cliff mines, looking west 


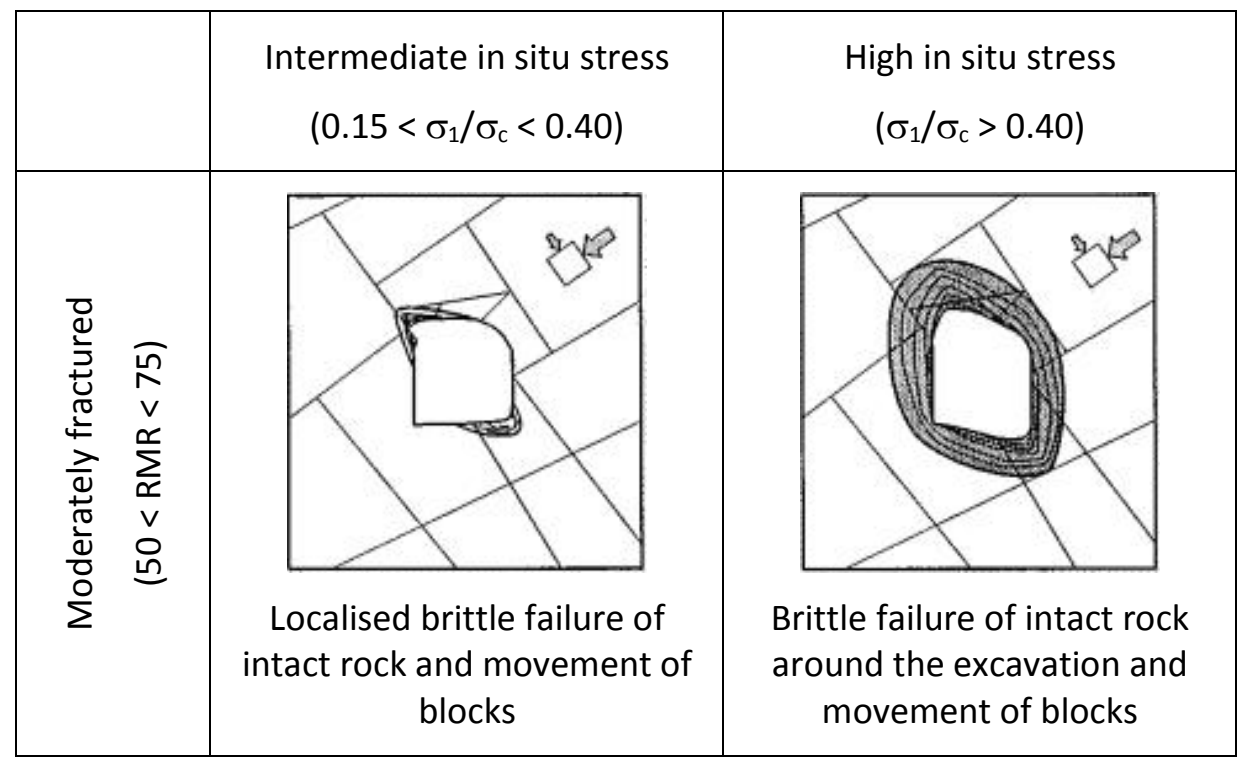

\section{Figure 2 Potential for tunnel instability and brittle rock mass failure at Creighton and Copper Cliff mines, modified from Martin et al. (1999)}

The mine sites were selected for this investigation based on their history of rockbursts and the quality of their seismic data. Creighton Mine has operated a calibrated seismic monitoring system for many years. For the purposes of this project, the collection of rockburst data at Creighton has covered events from January 2000 to September 2013. At Copper Cliff Mine, the operation of a calibrated seismic monitoring system began in 2004. Data from January 2004 to September 2013 were collected and analysed for Copper Cliff.

In the collected rockburst data, the severity of each rockburst was assessed using visual estimates of the displaced tonnage provided for each damage location. The evolution of the frequency and severity of rockbursts can be represented by the cumulative displaced tonnage over time, given that the complete rockburst history has been collected over the studied time period (Figure 3 ).

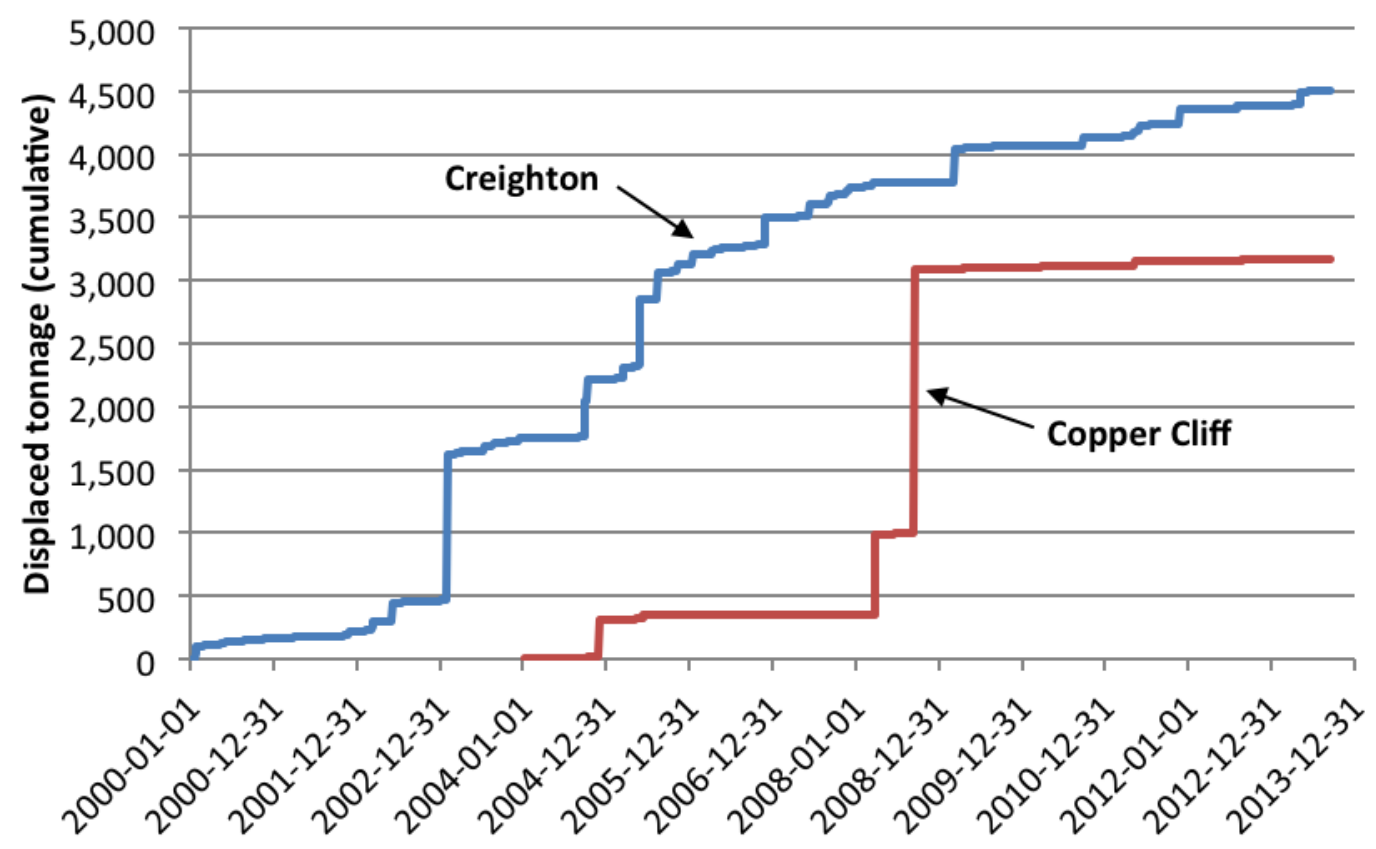

Figure 3 Cumulative tonnage displaced over time as a result of rockbursts at Creighton and Copper Cliff mines 
Rockbursts have been regular occurrences at Creighton, as compared to Copper Cliff. This is reflected by the steady increase of the cumulative displaced tonnage at Creighton (Figure 3). Copper Cliff Mine has been occasionally affected by very severe rockbursts, which generated displacements of important amounts of material. However, the rate of displaced tonnage at Copper Cliff has been generally low between severe events. Such contrast in the evolution of the frequency and severity of rockbursts might reflect the experience gained at Creighton while dealing with increasingly high stress environments. Since 2004, Creighton experienced the least amount of rock displaced due to rockbursts, despite being the deepest of the two mines and the one that faced rockbursts the most frequently. The evolution of the frequency and severity of rockbursts at Creighton and Copper Cliff Mine is analysed in greater detail in the following section where specific case studies are discussed.

\section{$3 \quad$ Evolution of mining and support practice}

\subsection{Creighton Mine}

The 400 and 461 orebodies (Figure 1) have been mined at Creighton over the time period covered by this study. Most of the ore extraction took place in the deep part of the mine, i.e. below the 6400 level $(1,950 \mathrm{~m})$. Currently, the majority of economic mineralisation has been depleted down to the 7400 level $(2,255 \mathrm{~m})$ in the Deep 400 orebody and to the 7840 level $(2390 \mathrm{~m})$ in the 461 orebody.

\subsubsection{Stope design and seismic risk management}

At Creighton Mine, the occurrence of rockbursts appears to be influenced by the depth and maturity of mine levels. A noticeable increase in the total number of rockbursts is observed as the mine depth approaches the 7400 level $(2,255 \mathrm{~m}$ ) (Figure 4). Open stopes varying from 53-60 m height were mined at levels above $2,255 \mathrm{~m}$ depth, in the 400 orebody. Below the 7400 level, the spacing between top and bottom sills had been reduced to $40 \mathrm{~m}$, in anticipation of higher stress conditions at greater depths and to better delineate the mineable reserves. The crown of the first stope mined between the 7400 and 7530 levels in the 400 orebody was blasted in April 2004. Since 2005, the majority of stopes were mined below the 7400 level. Mining in the 461 orebody began in 2006. Recognising the unfavourable orientation of the orebody with respect to the major principal stress, reflected by seismic activity in the area over the last several years, the mine employed stopes with a design height of $26 \mathrm{~m}$. Fine-tuning stope design is an ongoing process at Creighton Mine.

Reducing the stope height at Creighton has likely contributed in preventing an escalation of seismic activity as the mine progressed to greater depths. The evolution of the rate of seismicity was assessed from January 2000 to September 2013 (Figure 5). The magnitude-time history analysis is a graphical technique which facilitates the assessment of the relationship between seismicity and the change in the stress field due to mining (Hudyma \& Potvin 2010, p. 897). An increase in the rate of seismicity can be observed starting September 2001, and then accelerating in September 2002 up to April 2003. The increase in seismicity during this period was exacerbated by mining a foot wall extension of the 400 orebody between the 7000 and 7200 levels, which generated stress concentrations in the vicinity of the Plum shear zone. This structure is currently amongst the most seismically active of ten major shear zones within Creighton Deep. Figure 6 illustrates the concentration of seismic events from January to April 2003 in the immediate foot wall of the 4487 stope mined in early 2003. These events, of reported magnitude greater than $0.8 \mathrm{M}_{\mathrm{N}}$, coincide with the observed high stress conditions in this area. Mining-induced stresses were assessed using Map3D (Wiles 2014), a 3D elastic boundary element model. Mine seismicity decayed from April to August 2003 due to a labour interruption. A similar decay of the rate of seismicity was observed during the more recent production interruption in 2009-2010. Grey-shaded areas illustrate the two periods of production interruption (Figure 5). Between these two periods, the rate of seismicity remained fairly constant. A slight decrease, however, is observed starting in late 2005 and therefore could be attributed to mining stopes of smaller dimensions in the 400 orebody. Finally, a temporary slow-down in mine production, which occurred in early 2012, is also detected on the magnitude-time history chart. 

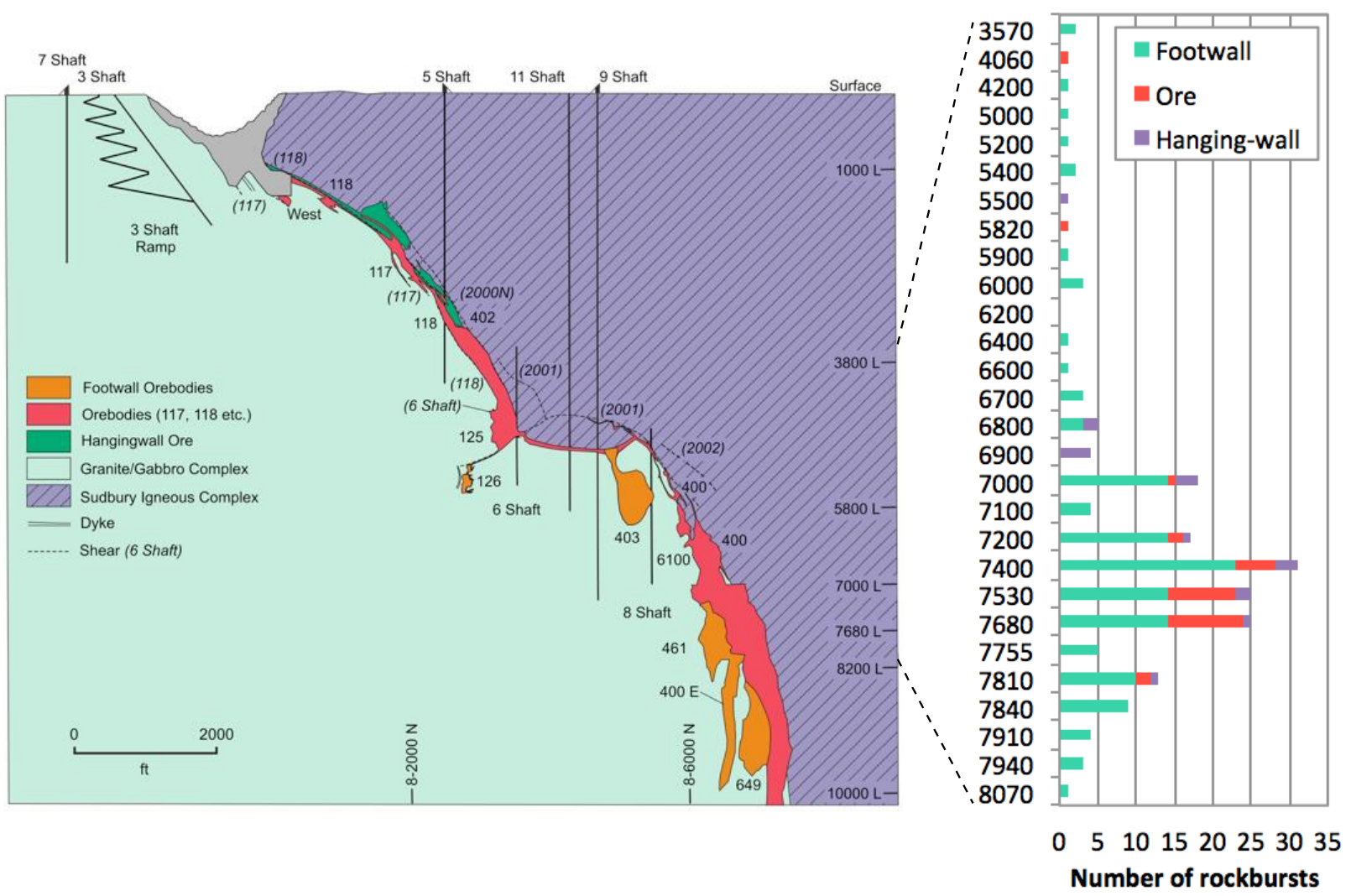

Figure 4 Influence of depth and maturity of mine levels on the occurrence of rockbursts at Creighton Mine (cross-section looking west)

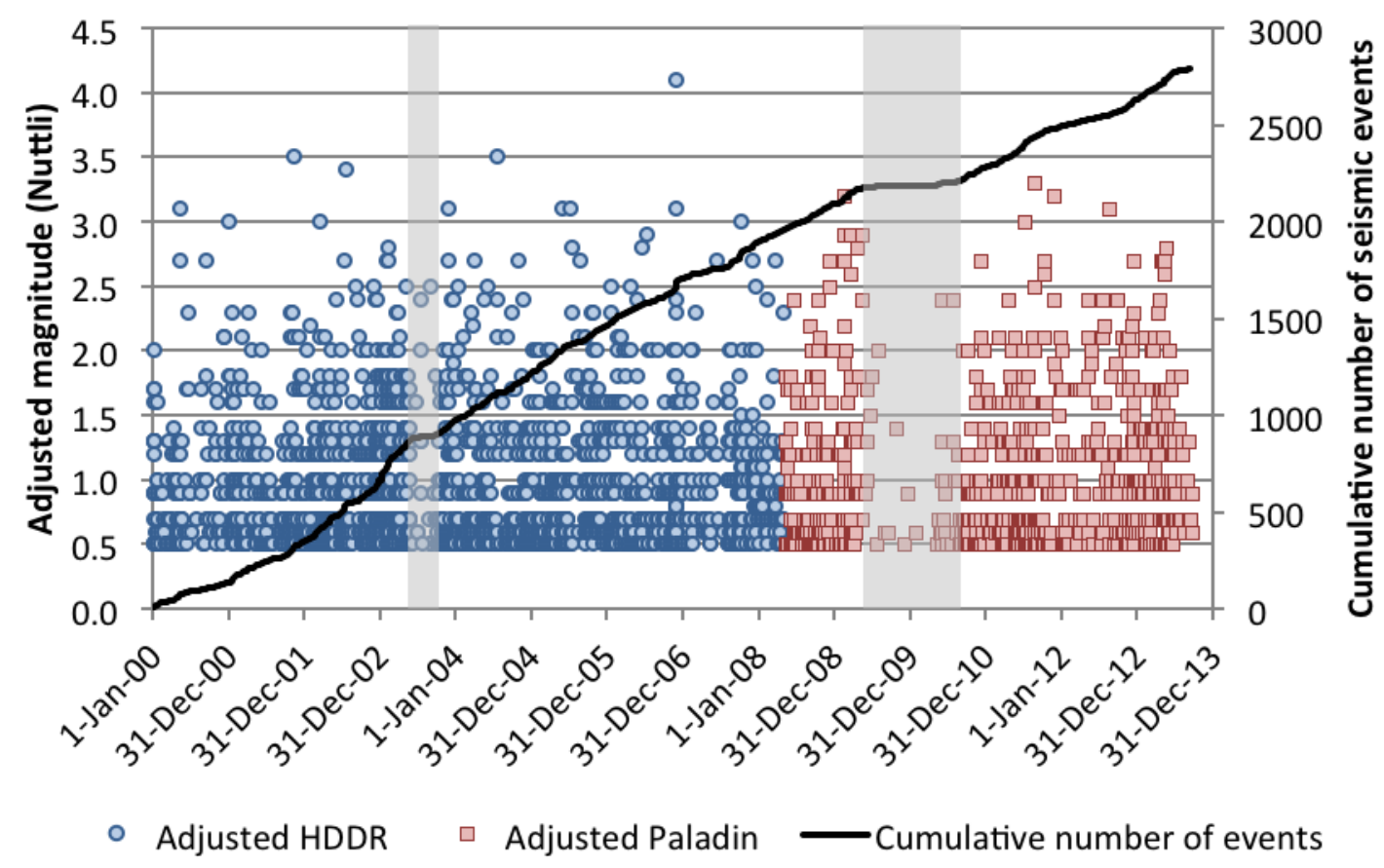

Figure 5 Magnitude-time history of Creighton Mine showing magnitude events greater than $0.5 \mathrm{M}_{\mathrm{N}}$ 


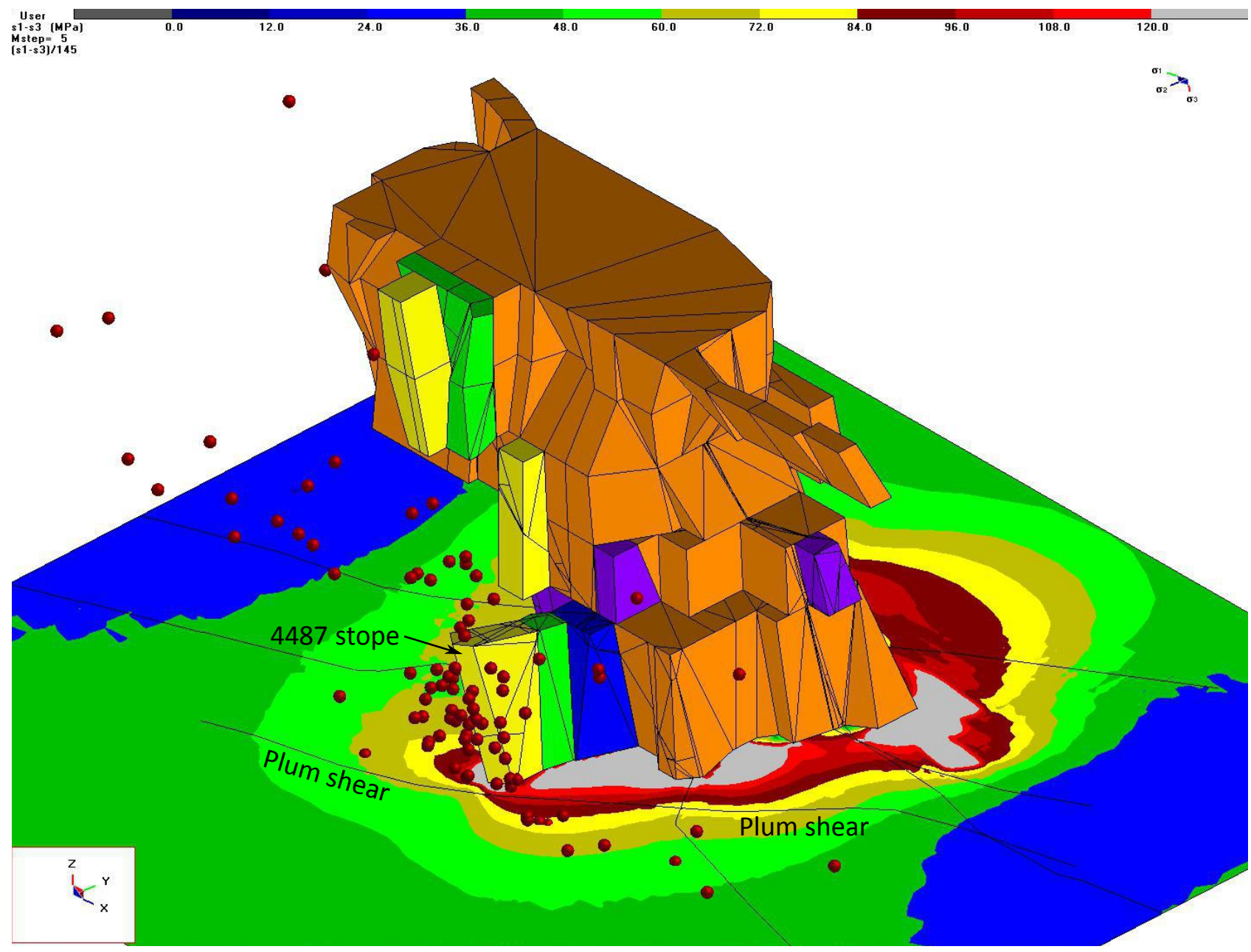

\section{Figure 6 Differential stresses and seismicity associated with mining of the $\mathbf{4 0 0}$ orebody towards the Plum shear on the 7200 level in 2003}

This analysis demonstrated that, although mining has influenced seismicity at Creighton Mine, the seismic hazard has been adequately managed. This was reflected by the relatively constant rate of mining-induced seismicity over time, despite mining at greater depth and within the unfavourable stress conditions associated with the 461 orebody. The magnitude-time history analysis corroborated the engineering decision of making adjustments to the stope design in anticipation of higher stress environments in the 400 and 461 orebodies. This case study exemplified that in deep underground mines, the role of engineering is not to eliminate seismicity, which could only happen by shutting down production, but to manage it.

This analysis was made in consideration of the two seismic monitoring systems used at Creighton Mine: the HDDR from 2000 to May 2008 and the Paladin from May 2008 to 2013. The magnitudes provided by the two systems were adjusted in order to compare with the Nuttli magnitude scale used by the Geological Survey of Canada (GSC). This adjustment was made possible by considering seismic events that were reported by both the seismic monitoring system used onsite at the time and the GSC (Figure 7). The adjustment was validated further using the magnitude-time history chart in order to ensure that no change in the rate of seismicity could be attributed to the change of seismic monitoring system. 


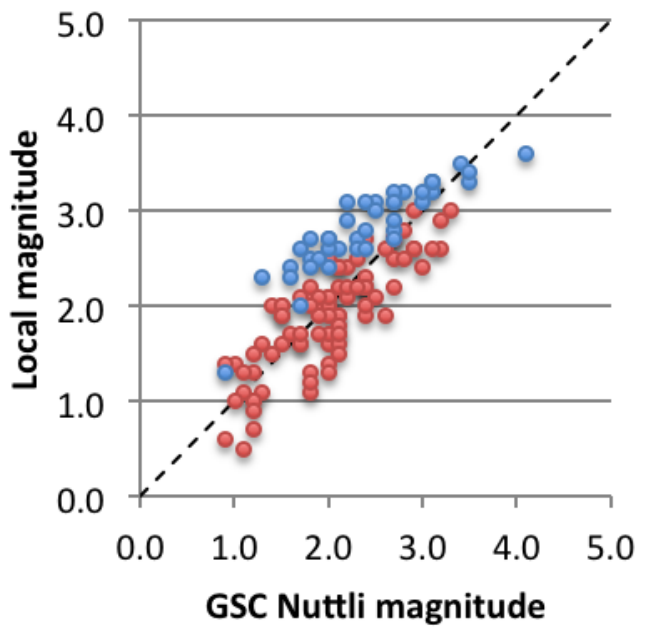

- Paladin $\odot$ HDDR - - - 1:1 reference

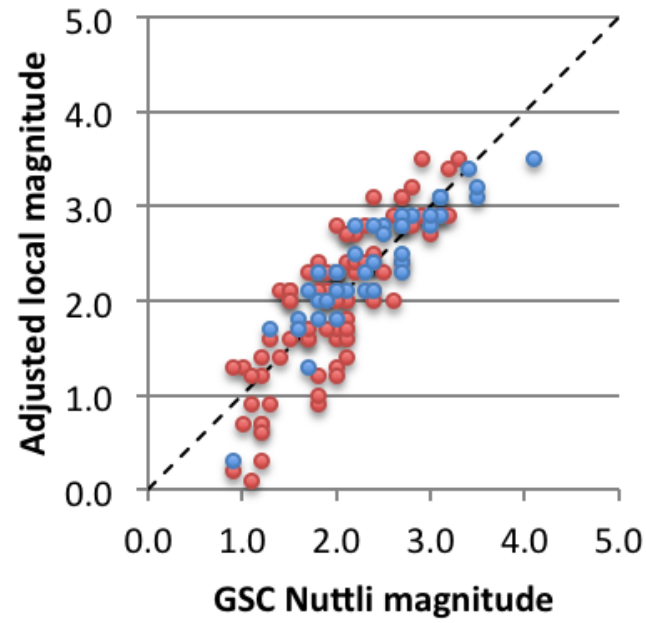

- Paladin' $\odot$ HDDR' $----1: 1$ reference

(a)

(b)

\section{Figure 7 Adjustments to the event magnitudes captured by the HDDR and Paladin seismic monitoring systems in order to ensure proper calibration to the GSC}

\subsubsection{Evolution of ground support systems}

Ground support practices at Creighton Mine evolved as mining progressed to greater depths. The mine began to install modified cone bolts (MCB) in conjunction with \#0/0 gauge straps as part of its 'enhanced' ground support system in December 2004. In February 2005, a $2 \mathrm{~m}$ long, $46 \mathrm{~mm}$ diameter friction set was introduced. This bolt replaced the $1.7 \mathrm{~m}$ long, $35 \mathrm{~mm}$ diameter friction set and its predecessor, a $39 \mathrm{~mm}$ version used in the walls of mine excavations (Punkkinen \& Yao 2007). As of November 2006, the minimum ground support standard consisted of a diamond pattern of $2.4 \mathrm{~m}$ long resin rebars and mechanical bolts in the back and $2 \mathrm{~m}$ long $46 \mathrm{~mm}$ friction sets in the walls. Reinforcement elements were installed on a $1.2 \times 1.5 \mathrm{~m}$ diamond pattern, overlapping \#4 gauge galvanised welded-wire mesh down to floor level. Shotcrete was frequently applied over the mesh to provide further surface support. In areas of the mine susceptible to rockbursts, the support standard was enhanced by adding $2.4 \mathrm{~m}$ long modified cone bolts and \#0/0 gauge straps (Malek et al. 2008), (Figure 8(a)).

The use of mechanical bolts at Creighton Mine was discontinued in June 2010 in response to corrosion issues and inadequate performance under dynamic loads. In September 2010, MCB33 (modified cone bolts for installation into $33 \mathrm{~mm}$ diameter boreholes) became part of the primary support system below the 7810 level, in areas where enhanced support is prescribed. MCB33 are installed along with resin rebars on a dense, $1.2 \times 1 \mathrm{~m}$, diamond pattern. \#0/0 gauge mesh squares $(0.3 \mathrm{~m})$ are installed in order to enhance the connection between the \#4 gauge screen and the reinforcement elements and to protect the surface support from being damaged by the cutting action of the plates (Figure 8(b)). The support system in the walls was enhanced further with the addition of modified cone bolts and $\# 0 / 0$ gauge squares in areas susceptible to rockbursts. Shotcrete, however, is no longer part of a minimum support standard as it was observed that it could not effectively manage higher dynamic loads and often resulted in cracking and spalling, which repeatedly called for rehabilitation. Shotcrete, however, is still used regularly on lower walls and pillar noses of bottom sills to prevent damage caused by production equipment or to rehabilitate damaged mine openings. Large diameter inflatable bolts are often used in rehabilitation and in areas where the presence of highly fractured rock mass does not facilitate the use of resin-grouted bolts. 


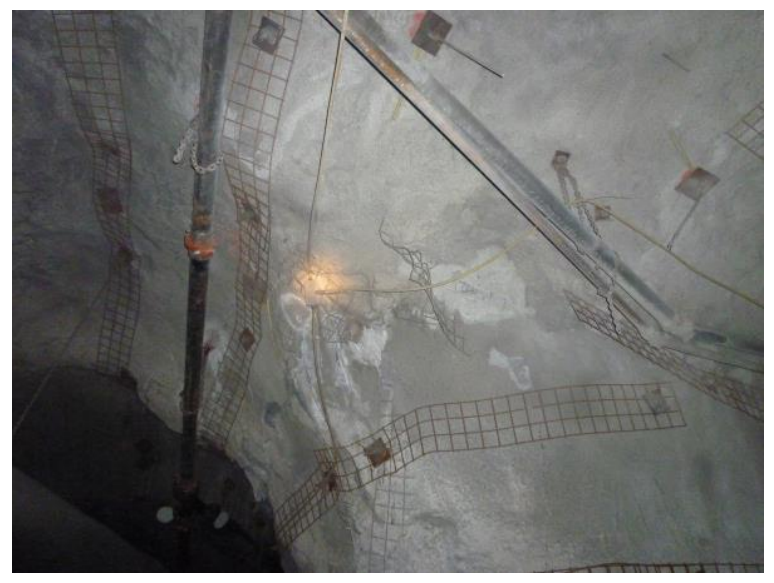

(a)

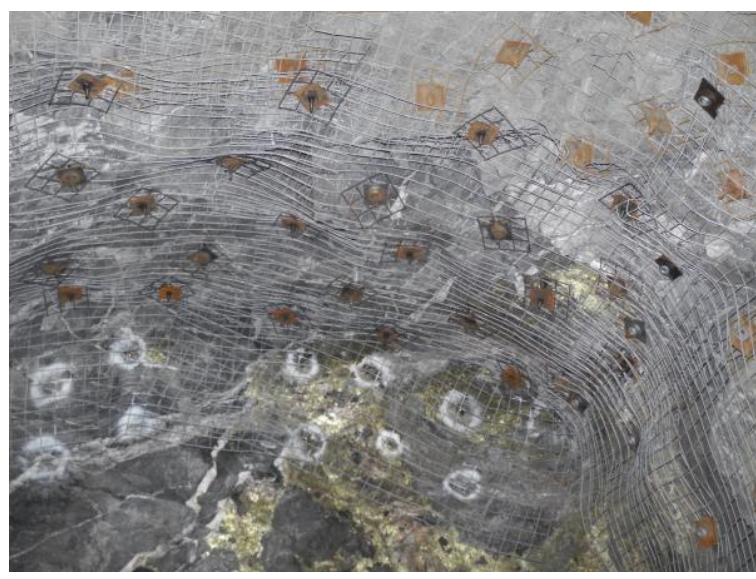

(b)

Figure 8 Evolution of the support systems used in areas susceptible to rockbursts at Creighton Mine with the support systems used from (a) 2006-2010; and (b) 2010 to date

Ground control personnel at Creighton Mine monitored the performance of individual reinforcement and surface support elements over time in order to identify limitations in the employed support system. A dome washer has been added between rebars and plates following observations of rebar failures in the threaded portion of the tendon through 2011 and 2012 (Vale 2012). It was identified that employing a flat plate often resulted in bending or shearing of the threaded end upon installation, in locations where boreholes were not drilled perfectly perpendicular to the back of excavations. The mine has used FS-46 bolts successfully with the traditional crimp design of the bushing. Observation of crimp failures through 2011 and 2012, however, suggested the limitation of this configuration for the high-stress bottom sills of the 461 orebody and motivated the adoption of a welded-ring design. Pull-tests conducted on site demonstrated that the capacity of the ring was enhanced from 9.1-10 $t$ to $15.5-16.3 \mathrm{t}$ with the most recent design (Vale 2012). Furthermore, as part of continuous efforts to explore new support strategies, the mine was, as of September 2013, investigating the performance of the D-bolt on its 7910 level.

\subsubsection{Cable bolting of large excavations}

Cable bolting at Creighton Deep is done systematically in all intersections where development headings are greater than $5 \times 5 \mathrm{~m}$. In practice, the mine cable bolts all excavations having a span greater than $7.3 \mathrm{~m}$ as per the support standard reviewed in June 2005. Cable bolts are also employed where geological structures, high walls, dynamic loading conditions, or ground conditions warrant, upon request of the ground control department (Vale 2012). Double $16 \mathrm{~mm} \mathrm{(5/8")} \mathrm{plated} \mathrm{cables} \mathrm{are} \mathrm{typically} \mathrm{installed} \mathrm{on} \mathrm{a}$ $2.1 \times 2.1 \mathrm{~m}$ pattern. For excavations spans smaller than $12 \mathrm{~m}$, the pair of cement-grouted cables installed within $50 \mathrm{~mm}$ diameter drill holes consists of a $6.4 \mathrm{~m}$ long birdcage strand cable and a $5.5 \mathrm{~m}$ long plain strand cable.

A systematic review of rockburst occurrences at Creighton Mine indicated that in large excavations (span or wall height $>7.3 \mathrm{~m}$ ), the installation of cable bolts tended to enhance the overall performance of the employed support system (Table 1). This was reflected by the increased severity of damage, represented by the reported displaced tonnage, in areas where cable bolts were not part of the support system. The advantage of using cable bolts can be attributed to their capacity of tying the support back to stable ground due to the additional length. It may, furthermore, be attributed to the softer behaviour of cable bolts as opposed to other reinforcement elements. Creighton Mine uses a combination of birdcage and plain strand cables. Birdcage cables provide an immediate stiff load response, which is desirable in highly fractured ground, whereas the plain strand cables are capable of withstanding moderate dynamic loading conditions (Hutchinson \& Diederichs 1996). 
Table 1 Rockburst occurrences prior to and after 2005 in excavations characterised by a span or wall height greater than $7.3 \mathrm{~m}$ at Creighton Mine

\begin{tabular}{c|ccccc}
\hline $\begin{array}{c}\text { Reported } \\
\text { installation of } \\
\text { cable bolts }\end{array}$ & $\begin{array}{c}\text { Number of } \\
\text { rockbursts }\end{array}$ & $\begin{array}{c}2000-2005 \\
\text { Tonnage displaced } \\
\text { from behind the } \\
\text { support }(t)\end{array}$ & $\begin{array}{c}\text { Number of } \\
\text { rockbursts }\end{array}$ & $\begin{array}{c}2006-2013 \\
\text { Tonnage displaced } \\
\text { from behind the } \\
\text { support (t) }\end{array}$ \\
\hline Yes & 5 & 227 & 11 & 73 \\
No & 9 & 2,021 & 4 & 122 \\
\hline
\end{tabular}

\subsubsection{Discussion}

The majority of changes in stope dimensions and support practice at Creighton were initiated between 2004 and 2005. Recent modifications to the enhanced support system became part of the standard in 2010. The evolution of the frequency and severity of rockbursts at Creighton (Figure 3 ) shows strong correlation with these changes. As ground support practice was modified for deep and high stress conditions, a significant decline in the rate of rockburst damage was observed.

\subsection{Copper Cliff Mine}

Copper Cliff Mine, although not being as deep and seismically active as Creighton, has encountered very severe, although sporadic rockbursts since 2004. The most severe ones occurred on 25 March and 11 September 2008. On 25 March 2008, a recorded $2.9 \mathrm{M}_{\mathrm{N}}$ seismic event generated over $635 \mathrm{t}$ of displaced material on the 3880 level of the 900 orebody. The seismic source was located in the vicinity of the Trap Dyke, one of the most prominent and seismically active geological structures at the mine (Hudyma \& Brummer 2007), which is located between the 100 and 900 orebodies (Figure 1). The damaged areas at the time were supported using a combination of $1.8 \mathrm{~m}$ long mechanical bolts and rebars in the back and $1.7 \mathrm{~m}$ long $39 \mathrm{~mm}$ friction sets in the walls, with the possibility of mechanical bolts having been installed as well. The surface support consisted of \#6 welded-wire mesh overlapped with plain shotcrete. In intersections, $6.4 \mathrm{~m}$ long cable bolts were installed on a $2.1 \times 2.1 \mathrm{~m}$ pattern. Pictures (Figure 9) of the most severely damaged areas revealed a complete collapse of the surface support and failure of several friction sets and mechanical bolts found in the muck pile (Razavi 2008).

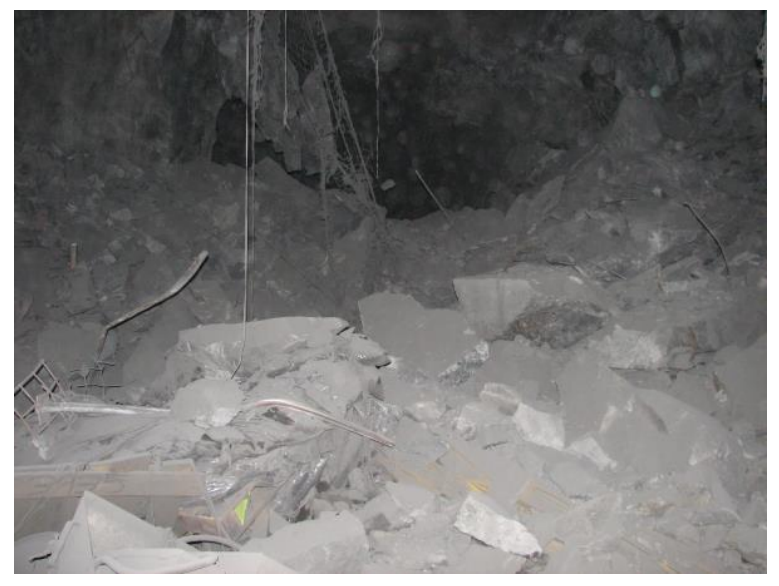

(a)

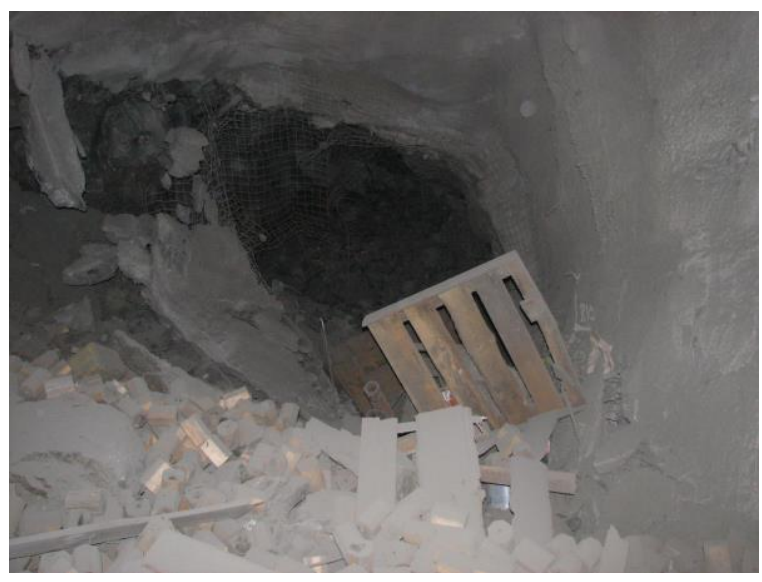

(b)

Figure 9 Damage on the 3880 level of the 900 orebody, at Copper Cliff Mine, triggered by a recorded $2.9 \mathrm{M}_{\mathrm{N}}$ seismic event on 25 March 2008 (Razavi 2008)

The 11 September 2008 rockburst was the result of a series of 10 seismic events that ranged from 1.2-3.8 $\mathrm{M}_{\mathrm{N}}$ and occurred from $0721 \mathrm{hrs}$ to $0806 \mathrm{hrs}$ (Yao et al. 2009). The series of events was triggered by 
the crown blast of the 94561 stope in the upper 100 orebody ( 3050 to 3200 level) at $0721 \mathrm{hrs}$. The seismic events resulted in damage to mine excavations from the 2700 level down to the 3710 level. The rockburst displaced an estimated total of $2,100 \mathrm{t}$ as the most prominent damage mechanism was interpreted as seismic shakedown due to the $3.8 \mathrm{M}_{\mathrm{N}}$ event (Suorineni \& Vasak 2008). The most severe damage, estimated to $1,500 \mathrm{t}$, occurred in the mine ramp between the 3500 to 3550 levels (Figure 10(a)). The reported depth of failure extended far beyond the primary reinforcement, varying from 3-6 $\mathrm{m}$.

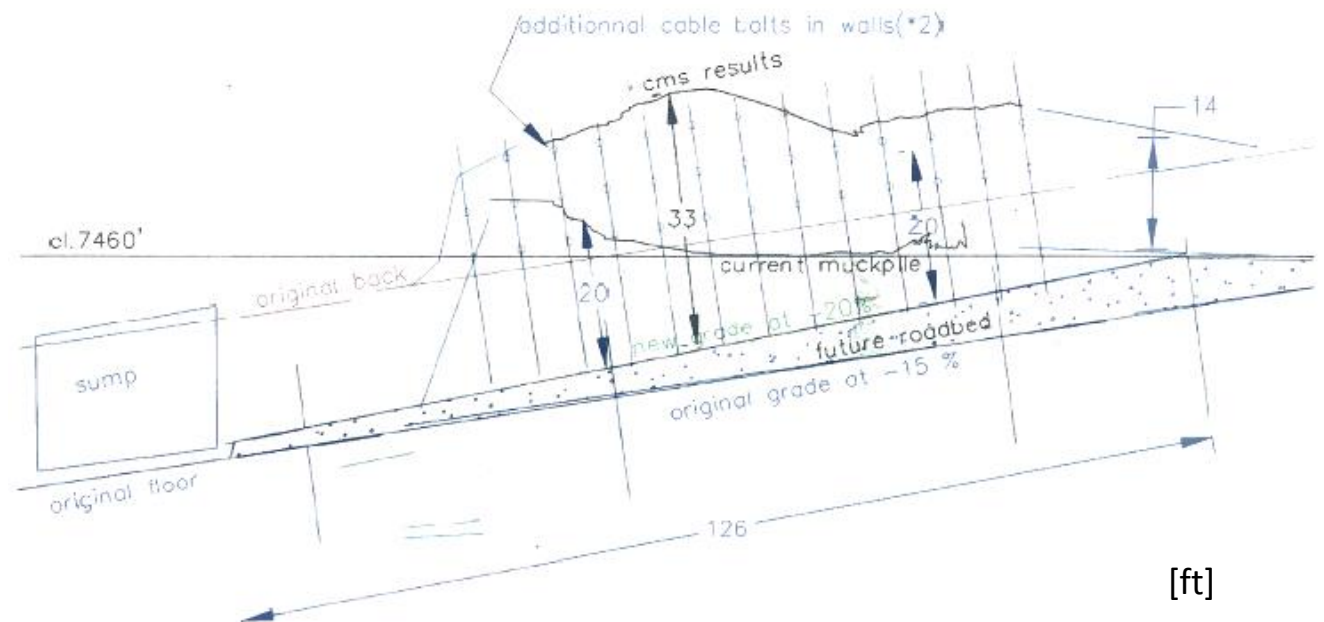

(a)

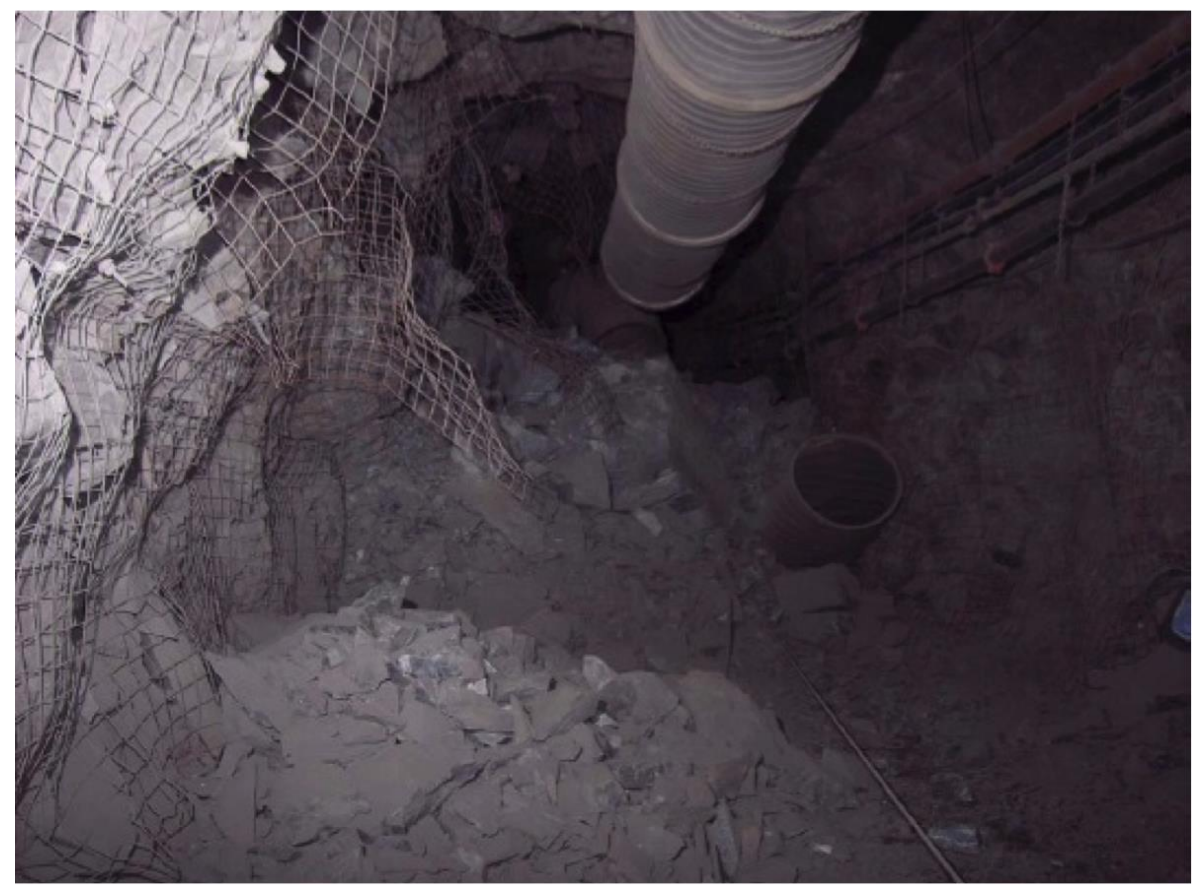

(b)

Figure 10 Damage to the Copper Cliff Mine ramp as a result of a $3.8 \mathbf{M}_{\mathrm{N}}$ seismic event on 11 September 2008;

(a) cross-section of the ramp between the 3500 and 3550 levels; and (b) photography of the $181 \mathrm{t}$ of material displaced where the ramp intersects the Trap Dyke between the $\mathbf{3 0 0 0}$ and $\mathbf{3 0 5 0}$ levels

The other three most severely damaged areas consisted of the section of the ramp between the 3000 to 3050 levels (Figure 10(b)), the return air drift on the 3500 level, and the 3710 level foot wall drift. The 
damage to mine excavations and support systems in these three areas was localised at the intersection with the Trap Dyke and was estimated at 181, 363, and $91 \mathrm{t}$, respectively. The ramp, as well as the majority of excavations affected by the 11 September 2008 rockburst were supported, using a diamond pattern of $1.8 \mathrm{~m}$ long mechanical bolts and rebars in the back and $1.8 \mathrm{~m}$ long mechanical bolts in the walls (Chinnasane 2009). The surface support in the damage locations generally consisted of \#6 welded-wire mesh, however, on the 3200 and 3710 levels, plain shotcrete was applied over the mesh.

Although the damage was typically less severe in areas where shotcrete was applied (Figure 11) the support system employed generally did not perform satisfactorily against seismic shaking during the 11 September 2008 rockburst (Suorineni \& Vasak 2008). The significant levels of rehabilitation caused by this event prompted a revision of the support practices at Copper Cliff Mine. Since 2008, many of the support elements successfully used at Creighton Mine have been introduced on site. At the present time, the minimum ground support standard employed at Copper Cliff consists of \#4 welded-wire mesh installed with 1.8 or $2.4 \mathrm{~m}$ long resin rebars in the back, depending on the size of the opening, and $1.7 \mathrm{~m}$ long $39 \mathrm{~mm}$ friction sets in the walls. The reinforcement is installed on a $1.2 \times 1.5 \mathrm{~m}$ diamond pattern. When burst-prone conditions are anticipated, the $39 \mathrm{~mm}$ friction sets are replaced by $46 \mathrm{~mm}$ friction sets. Shotcrete is applied over the mesh and $2.4 \mathrm{~m}$ long MCBs are installed in conjunction with \#0/0 gauge straps on a $1.2 \times 1.8 \mathrm{~m}$ pattern (Chinnasane et al. 2012). Furthermore, since 2008, the mining sequence has been adjusted by postponing the extraction of the 900 orebody in order to minimise the seismic hazard associated with mining on both sides of the Trap Dyke. Mining of the 900 orebody is planned to resume once the lower 100 orebody is mined completely (Vale 2010). Finally, preconditioning of rock masses became standard practice when developing in the vicinity of the Trap Dyke.



\section{Figure 11 Significant shotcrete cracking as the installed support system in the main intersection of Copper Cliff's 3200 level prevented the ejection of broken material on 11 September 2008}

From a ground control view, the use of de-stress blasting and adjustments to the mining sequence and ground support systems have been beneficial to Copper Cliff Mine. Since the 11 September 2008 event, only eight rockbursts have occurred at the mine. These rockbursts resulted in $91 \mathrm{t}$ of cumulated displaced rock mass from nine mine locations. Among these damage locations, only four withstood damage to the installed support system, i.e. in the remaining locations, the broken material was displaced from unsupported areas such as lower walls or development faces. Since 2008, the mine has been able to significantly reduce the rockburst hazard associated with production blasting. In effect, six of the eight 
rockbursts since 2008 were associated with development activities and three of them occurred while progressing through the Trap Dyke.

\section{$4 \quad$ Discussion and conclusions}

This paper reviewed the evolution of the frequency and severity of rockbursts at Creighton and Copper Cliff mines. Creighton Mine provided an excellent example of the evolution of ground support systems as mining progressed to higher stress environments. This level of commitment towards continuously improving support practices was attributed to the long history of significant seismicity. Correlations were identified between the improved performance in dealing with dynamic loading conditions at Creighton and changes in mining and ground support practice since 2004. Seismicity is a more recent phenomenon at Copper Cliff Mine, as reflected by the more recent installation of the seismic monitoring system. The high severity rockbursts of 2008 at Copper Cliff have necessitated a more immediate intervention in the ground support systems as opposed to the continuous evolution advocated at Creighton. In such case, lessons from Creighton Mine have provided a useful template.

This paper provided the baseline for a discussion on ground support practices applicable to dynamic loading conditions encountered in deep and high stress mining. The review of support performance over time has allowed the identification of general weaknesses in support systems when facing dynamic loading conditions. These weaknesses were either attributable to the support design or the in situ performance of the selected reinforcement or surface support elements (Table 2). Systematic installation of cable bolts in large excavations and the use of yielding reinforcement elements in conjunction with strong connecting elements such as heavy gauge straps can reduce rockburst hazard. This was demonstrated by the collected rockburst data from Creighton and Copper Cliff mines. The rate of rockburst severity, as represented in Figure 3, was significantly reduced after the introduction of yielding reinforcement elements in both mines. Since cable bolting in large excavations became more systematic at Creighton after 2005, part of the mine's success in managing dynamic loads have been attributed to this practice.

\section{Table 2 Identification of common weaknesses in ground support systems subjected to dynamic loadings}

Weakness
categories

Support design Absence of yielding bolts and strong connecting elements to enhance the energy absorption capacity of the support system.

Improper length of reinforcement elements in large excavations.

In situ Introduction of damage to reinforcement elements due to the installation process.

performance Failure of the crimp on friction set bolts.

Development of cracks within shotcrete or spalling.

Extension of the damage zone beyond the length of the employed reinforcement elements.

The role of shotcrete as a surface support element in support systems designed to manage dynamic loads has been questioned. It would appear that beyond a certain threshold of loading its effectiveness is diminished. Shotcrete can be perceived as not being able to manage dynamic loads due to its relatively high stiffness and its fundamentally brittle behaviour. This results in the development of cracks in shotcrete under high static and dynamic loads. The limitation of shotcrete in deep and high stress environments has been documented by Counter (2012). Nevertheless, shotcrete is capable of keeping the ground tight by limiting rock mass dilation as opposed to mesh, which is purely passive. As a result, shotcrete is capable, to a certain extent, of preserving a laminated beam and maintaining confinement around reinforcement elements (Simser 2012). The 3.8 $\mathrm{M}_{\mathrm{N}}$ seismic event at Copper Cliff Mine indicated that the use of shotcrete could be effective in preventing large seismic shakedowns. Recently, some high stress mines have adopted 
a mesh-over-shotcrete approach in order to better manage dynamic loads (Punkkinen \& Mamidi 2010; Counter 2012; Simser 2012). Such approach allows the shotcrete to keep the ground tight whereas the mesh can better absorb high levels of kinetic energy and accommodate larger deformations. The topic of shotcrete requires more attention in order to define its use as part of support systems designed for managing dynamic loads. Empirical experience developed over the analysis of rockburst case studies can contribute to the development of successful support strategies for mining at greater depth.

\section{Acknowledgement}

The authors acknowledge the financial support from Vale. Ground control personnel at Creighton and Copper Cliff mines are thanked for their continued technical assistance and for their contribution to this paper.

\section{References}

Chinnasane, DR 2009, Unusual Occurrence Report for Rockburst NM-117, Vale, Sudbury.

Chinnasane, DR, Yao, M, Landry, D \& Paradis-Sokoloski, P 2012, 'Performance of dynamic support system in highly burst-prone ground conditions at Vale's Copper Cliff Mine - a case study', in Y Potvin (ed.), Proceedings of the 6th International Seminar on Deep and High Stress Mining, Australian Centre for Geomechanics, Perth, pp. 57-69.

Counter, DB 2012, Support system evolution at Kidd Mine, presented at the Dynamic Ground Support Applications Symposium, Workplace Safety North, Sudbury.

Hudyma, M \& Brummer, R 2007, Copper Cliff North Mine Seismicity Review: 2004-2006, Itasca Consulting Canada Inc., Sudbury.

Hudyma, M \& Potvin, YH 2010, 'An engineering approach to seismic risk management in hardrock mines', Rock Mechanics and Rock Engineering, vol. 43, pp. 891-906.

Hutchinson, DJ \& Diederichs, MS 1996, Cablebolting in Underground Mines, BiTech Publishers Ltd, Richmond.

Kaiser, PK \& Cai, M 2013, 'Critical review of design principles for rock support in burst-prone ground - time to rethink!', in Y Potvin \& B Brady (eds), Proceedings of the Seventh International Symposium on Ground Support in Mining and Underground Construction, Australian Centre for Geomechanics, Perth, pp. 3-38.

$\mathrm{Li}, \mathrm{CC} 2010$, 'Field observations of rock bolts in high stress rock masses', Rock Mechanics and Rock Engineering, vol. 43, pp. $491-496$.

Li, CC 2012, 'Performance of D-bolts under static loading', Rock Mechanics and Rock Engineering, vol. 45, pp. 183-192.

Li, CC \& Doucet, C 2012, 'Performance of D-Bolts under dynamic loading', Rock Mechanics and Rock Engineering, vol. 45, pp. 193-204.

Malek, F, Trifu, C, Suorineni, FT, Espley, S \& Yao, M 2008, 'Management of high stress and seismicity at Vale Inco Creighton Mine', Proceedings of the 42nd US Rock Mechanics Symposium, American Rock Mechanics Association, Alexandria.

Martin, CD, Kaiser, PK \& McCreath, DR 1999, 'Hoek-Brown parameters for predicting the depth of brittle failure around tunnels', Canadian Geotechnical Journal, vol. 36, no. 1, pp. 136-151.

Mines and Aggregates Safety and Health Association 2009, Technical report - Unusual occurrence report for groundfall/rockburst, MASHA, North Bay.

Morissette, P, Hadjigeorgiou, J \& Thibodeau, D 2014 'Investigating the dynamic-load demand on support systems using passive monitoring data', International Journal of Rock Mechanics and Mining Sciences, vol. 67, pp. 115-126.

Punkkinen, AR \& Mamidi, NR 2010, 'Effective ground support system design to manage seismic hazard in a high stress diminishing pillar at a Vale mine', in Y Potvin \& M Van Sint Jan (eds), Proceedings of the Fifth International Seminar on Deep and High Stress Mining, Australian Centre for Geomechanics, Perth, pp. 367-381.

Punkkinen, AR \& Yao, M 2007, 'Change of ground support system and mining practice in the Deep at Creighton Mine', Proceedings of the CIM Conference and Exhibition 2007, Canadian Institute of Mining, Metallurgy and Petroleum, Westmount.

Razavi, M 2008, Unusual Occurrence Report for Rockburst NM-115, Vale, Sudbury.

Simser, B 2012, Ground support in "deep" underground mines, presented at the Dynamic Ground Support Applications Symposium, Workplace Safety North, Sudbury.

Stacey, TR 2012, 'Support of excavations subjected to dynamic (rockburst) loading', in Q Qian \& Y Zhou (eds), Proceedings of the 12th ISRM International Congress on Rock Mechanics, International Society for Rock Mechanics, Lisboa, pp. 137-145.

Suorineni, FT \& Vasak, P 2008, Expert Opinion Report on North Mine Seismic Events of September 11th 2008, Mirarco, Sudbury.

Vale 2010, 'Mining methods', in DR Chinnasane (ed.), Copper Cliff Mine - 2010 Mine Design Package, Vale, Sudbury.

Vale 2012, 'Ground support', in A Punkkinen (ed.), Plant 17 Creighton Mine - Mine Design Package 2012 Update, Vale, Sudbury.

Wiles, T 2014, Map3D, version 62, Mine Modelling Pty Ltd, Mt. Eliza, http://www.map3d.com

Yao, M, Chinnasane, DR, \& Harding D 2009, 'Mitigation plans for mining in highly burst-prone ground conditions at Vale Inco Copper Cliff North mine', in M Diederichs \& G Grasselli (eds), Proceedings of the 3rd CANUS Rock Mechanics Symposium, Canadian Rock Mechanics Association, Toronto. 
The influence of change in mining and ground support practice on the frequency and severity of rockbursts 